Tuchkina I. A., Dobrovolskaya L. A., Tuchkina M. Yu. Incidence, clinical presentation and treatment of dysmenorrhea in female adolescents depending on the nature of extragenital background. Journal of Education, Health and Sport. 2019;9(11):175-184. eISSN 2391-8306. DOI http://dx.doi.org/10.5281/zenodo.3552805

https://apcz.umk.pl/czasopisma/index.php/JEHS/article/view/27995

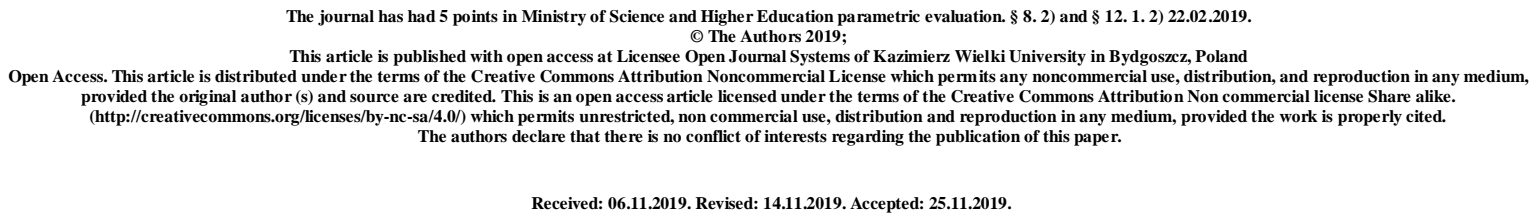

UDC 618.011-008.6

\title{
INCIDENCE, CLINICAL PRESENTATION AND TREATMENT OF DYSMENORRHEA IN FEMALE ADOLESCENTS DEPENDING ON THE NATURE OF EXTRAGENITAL BACKGROUND
}

\author{
I. A. Tuchkina, L. A. Dobrovolskaya, M. Yu. Tuchkina
}

\section{Kharkiv National Medical University (Ukraine)}

\section{Abstract}

Incidence of dysmenorrhea in female adolescents was shown to be $28.4 \%$ of all gynecological disorders (41\%). The study involved treatment of 88 girls aged 14-18 by complex of non-hormonal and physiotherapy.

The effectiveness of complex non-hormonal therapy for gynecological patients was 76.6-83.3\%. No side effects and complications were observed. For most of patients the positive effect of treatment was preserved for 2-3 months.

Keywords: dysmenorrheal; female adolescents; non-hormonal therapy.

Relevance. The leading role in the structure of specialized services in adolescence is played by timely gynecological assistance to adolescent girls with the most frequent pathological conditions in pediatric gynecology, namely menstrual dysfunction (MD) [I, 2]. It does not always adequately respond to therapy, which is explained by the complexity of the diagnostic methodology in most of cases, often by an endocrine nature [3, 4]. According to most experts, the most common MD in women is dysmenorrhea syndrome (DS), which 
occurs at a frequency of $22-75 \%$ during puberty, significantly impairing the quality of life of teenage girls $[1,5,6]$.

Primary DS is a cyclically recurring pain syndrome, which is caused by a complex of neurovegetative, metabolic and behavioral disorders accompanying menstrual endometrial abruption. Pain as a feeling of suffering is a frequent reason for young patients to turn to a gynecologist, although painful menstruation is often seen by young patients as a matter of course. Primary DS, observed in most patients, leads not only to disability, but also to severe changes in psychosomatic status [5, 7].

Currently, most researchers associate primary DS with a high level of prostaglandins (PG) F2a and E2 and / or an increase in the ratio of PGF2a / PGE2 in the endometrium, which are powerful stimulants of the contractile activity of the myometrium. During the luteal phase of the menstrual cycle, the endometrium secretes of PG (an increase in the content of F2a of uterine origin coincides with regression of the corpus luteum). The presence of hormonal regulation of PG synthesis is evidenced by a positive correlation between the high level of PGF2a in the middle and late periods of the secretory phase of the cycle and the level of PGE2. The stimulating effect of estrogen on the synthesis of PG and progesterone (PRH) has been proven $[6,7]$.

In the process of studying DS pathogenesis, it was found that during menstruation the integrity of the membranes of the endometrial cells is impaired, and PG from the cells enter the intercellular space. Endometrial abruption leads to an increase in their content in menstrual blood. In turn, a high level of PG is accompanied by an increase in contractile activity of the uterus, vasospasm and local ischemia, which causes pain, since the disruption of the pelvic hemodynamics in the form of hypertension and vasospasm or prolonged vasodilation and venous stasis contributes to cell hypoxia, accumulation of allogeneic substances, irritation of nerve endings and development of pain. The accumulation of potassium salts in the tissues and the release of free active calcium contribute to an increase in intrauterine pressure and the amplitude and frequency of uterine contractions by $2-2.5$ times compared with women with painless menstruation. The key mechanisms for the development of pain in DS are central, vascular, and prostaglandin ones. The prostaglandin mechanism is manifested by an increase in the synthesis of prostaglandins (predominantly F2a and E2) or a predominance of the synthesis of F2a, which are stimulants of the contractile activity of the myometrium, an increase in the sensitivity of nociceptors to stimuli, and activate silent nociceptors. Increased concentration of PG in the blood can result in ischemia of other organs and tissues, which leads to extragenital (neurological) disorders in the form of headache, 
vomiting, diarrhea, heart pain, tachycardia, etc. [6, 7].

Given the figurative expression of Academician V.N.Serov that pain should not be tolerated, and the doctor can and should offer effective and pathogenically substantiated treatment, the need to improve adequate specialized care for girls and young women determines the relevance of this study.

\section{The aim of the study}

To study the incidence of clinical presentation of DS, to evaluate the effectiveness of non-hormonal therapy and rehabilitation of this disorder in girls depending on the nature of extragenital background.

\section{Material and methods}

The study was conducted at the clinical base of the Department of Obstetrics, Gynecology and Pediatric Gynecology of Kharkiv National Medical University. The results of preventive examinations of secondary school students of Slobozhansky district of the city of Kharkiv aged 11-18 years for 2017-2018 were analyzed, which were carried out 2 times a year in accordance with the order of the Ministry of Health of Ukraine No. 434.

Diagnosis implied clinical, laboratory, biochemical, genetic, ultrasound (including Doppler) methods, computed tomography and magnetic resonance imaging were used according to indications. The nature of the functioning of the autonomic nervous system was evaluated. All patients were consulted by related specialists to identify the nature of extragenital pathology (EP).

\section{Results and their discussion}

Assessment of the data of preventive examinations of 12,641 adolescents over the past 3 years showed that menstrual dysfunction was of the highest incidence in the structure of gynecological disorders in teenage girls (41\% of the total number of gynecological diseases), the most common of which had DS (28.4\%).

To improve the examination of patients, a diagnostic algorithm has been developed for examining gynecological adolescent patients, consisting of 3 stages that are sequential and follow the principles of continuity, taking into account the nature of gynecological disorders at each stage [5].

Stage I screening; Stage II comprehensive outpatient examination; III stage inpatient examination. The use of such a systematic approach to diagnosis made it possible to establish at stage I that urgent care was needed for patients with severe and moderate forms of primary DS who were referred to the hospital for specialized medical care. At stages II and III of the diagnostic algorithm, an analysis of clinical and medical history data showed that $75 \%$ of 
examined with DS had EP. 50\% of them had 2 or more diseases. The study showed a relationship between the nature of EP and the severity of the clinical manifestations of DS. Mild pain syndrome (67.2\%) was more common in girls with diseases of the gastrointestinal tract, musculoskeletal system, and myopia. Dysmenorrhea of moderate severity (25.9\%) was more common in patients with disorders of the hepatobiliary, urinary systems and thyroid gland. A severe form of DS (6.8\%) was accompanied by metabolic-endocrine and neurovegetative manifestations, was detected in patients with cardiovascular and neurological diseases, often in combination with myopia. Dysmenorrhea in patients with EP was manifested against an unfavorable hereditary and premorbid background: every fourth patient was born in a state of asphyxia, every sixth with a decrease or excess of body weight, $45 \%$ of mothers had menstrual and reproductive function disorders, obstetric complications, and infertility in families. $71.6 \%$ of the mothers of the examined adolescents experienced painful menstruation throughout their lives, most of them before delivery. Besides, $34 \%$ of parents had occupational hazards and half of them had somatic illnesses. Adverse premorbid background was observed in $72 \%$ of patients. The characteristic clinical manifestations of DS are: pain in the lower abdomen in the first 1-3 days of severe intensity, with irradiation to the leg (usually the right one) or lumbar region, malaise, disability. In 56\% of examined patients, pains in the lower abdomen were accompanied by vasovegative and psychoemotional manifestations of different intensities (headache, dizziness, diarrhea, nausea, vomiting, chills, etc.).

The average age of menarche was 11 years 8 months \pm 9 months. Regular cycle was preserved in the majority of the examined; however, $20 \%$ of the girls noted a combination of pain with periodic small delays in menstruation (from 5-10 days to a month). In $84 \%$ of patients, the duration of menstruation was 5-7 days, with moderate blood loss, in $16 \%$ of patients with increased menstrual bleeding on the second day.

Physical and sexual development in patients with DS, as a rule, corresponded to age and most often was harmonious, deficient and excess body weight were observed in $10 \%$ of girls. The structure of morphotypes, bone age, and sexual development score (10.2 \pm 1.7$)$ did not significantly go beyond population parameters.

Physical examination of $15 \%$ of adolescent girls showed disorders of the mammary gland (mild fibrotic and fibrocystic mastopathy). The study of gynecological status showed that with a regular menstrual cycle, the size of the uterus corresponded to age parameters. Uterine echosonography data confirmed physical examination findings. The ovaries, as a rule, were not enlarged; in a third of patients they had a heterogeneous, multifollicular structure. 
Ultrasound examination was supplemented by color Doppler mapping.

Considering that primary DS is often based on mechanisms of local hyperproduction of eicosanoids, we performed an in-depth diagnosis of DS using a standard sample in our modification $[8,4]$ to confirm or exclude primary DS.

Based on the theory of DS development as a persistent pain syndrome, which is often based on an impairment of the synthesis and metabolism of arachidonic acid and its biologically active metabolic products (prostaglandins, leukotrienes, thromboxane, etc.), many researchers consider the use of non-steroidal anti-inflammatory drugs (NSAIDs) to be sufficient for treatment, in some cases, in combination with antioxidants $[5,6,7]$.

The research results show that selective NSAIDs can be used as the basic therapy of DS, which helps to reduce the enzymatic activity of cyclooxygenases, thereby reducing the level of eicosanoids and weakening the undesirable multiple effects of their overproduction. It is advisable to use NSAIDs at the initial examination stage in order to differentiate assessment of the main cause of DS [8]. At the same time, our earlier studies showed a higher efficiency of progestogens and COCs for the treatment of DS [9].

When evaluating the effectiveness of treatment with hormonal drugs, the severity of pain and, more rarely, the neuro-vegetative and emotional manifestations of DS, which are known to significantly aggravate the course of the disease and are especially often observed in the pubertal period, are often taken into account. Adolescence, during which the formation and development of the female body occurs, is a difficult stage in the formation of the reproductive system and therefore requires a very careful and gentle corrective approach to the choice of methodology for the treatment and prevention of relapses of the resulting MD. The use of drugs for the treatment of patients with gynecological diseases without taking into account the peculiarities of adolescence, administration of often unreasonable hormone treatments in dosages traditional for adult women, can have serious complications and adverse reactions for teenage girls. Unfortunately, hormonal agents of female sex hormones available today have a certain range of side effects and their use in young patients should be prescribed according to strict indications. In addition, as the present study showed, most of the examined patients with DS had somatic disorders in which administration of NSAIDs and hormonal medications should be limited or contraindicated. At the same time, in the treatment of patients with functional disorders of the menstrual cycle, including premenstrual syndrome, homeopathy remedies, medications of natural origin, the active components of which are derived from plant materials, have proven themselves well. Such agents have good tolerance and high safety, practically have no contraindications for use, act gently and regulate the 
reproductive system of the developing organism. Therefore, we have expanded the therapeutic effect in DS in adolescents due to more physiological, non-hormonal methods: complex homeotherapy (the use of Dysmenorm), physiotherapy (the use of microwave resonance therapy - MRT), local anti-inflammatory therapy (administration of Distreptaza).

The advantage of complex homeotherapy is the proven effectiveness in randomized, double-blind, placebo-controlled studies according to the GCP standard, with a high safety profile - the practical absence of side effects, the possibility of use and for prevention (which served as the basis for us to include Dysmenorm in rehabilitation schemes), the possibility of use in complex therapy with any other medications of natural origin, the active components of which are derived from plant materials, have proven themselves well and treatment methods (which formed the basis of DS treatment regimens that combine the use of Dysmenorm with MRT and Distreptaza).

Willow shrub (Agnuscastus, chaste tree), pulsatilla (Pulsatilla, meadow lumbago), rosemary (Rosmarinus officinalis), apis (Apis mellifica) contained in Dysmenorm are components of natural origin, have a complementary effect and their complex combination in one agent is intended for the treatment of patients with various DMs that are functional in nature. Our previous positive experience of the effective use of Dysmenorm for the treatment of DM in adolescents [10], was the basis for its use in the complex treatment of DS and the rehabilitation of these patients.

At the same time, its main pharmacological properties were taken into account: normalization of hormonal regulation of menstrual function (prolactin-inhibiting effect), antispasmodic, analgesic, decongestant, anti-inflammatory (due to improved local blood flow), antidepressant, sedative and tonic action.

The study involved 88 patients aged 14-18 years with DS. By the nature of the prescribed treatment, the patients were divided into 3 groups. Group I (30) patients underwent MRT in conjunction with administration of Dysmenorm, group II (30) was treated with a complex that included the use of Distreptaza in combination with Dysmenorm, group III (28) received traditional therapy, analgesics and antispasmodics.

Group I patients received MRT according to our previously developed method for 10 days [11]. Dysmenorm was prescribed at the same time, 2 tablets were used 2 times a day for a month, then 1 tablet 3 times a day in the first half of the cycle and 2 tablets 3 times a day in the second phase of the menstrual cycle for 2 months (total, at least 3 months), based on the fact that one tablet contains Agnus castus $125 \mathrm{mg}$ (dry residue $1.0 \mathrm{mg}$ ), Pulsatilla D3 $25 \mathrm{mg}$, Rosmarinus officinalis D2 25 mg, Apismellifica D3 25 mg. 
For patients of group II, treatment with Dysmenorm was prescribed differentially, depending on the day of the menstrual cycle at the time of the examination: 1 tablet 3 times a day from day 5 in the first phase of the cycle, 2 tablets 3 times a day in the second phase of the cycle sublingually half an hour before a meal or half an hour after a meal for 1-3 months. The basis for use in the complex of non-hormonal treatment of adolescents with DS of the drug Distreptaza was the following.

According to various authors, from 10 to $30 \%$ of patients with DS are resistant to NSAIDs. The concentration of PFF2a and PGE2 in the menstrual blood in these patients practically does not differ from those in the control group.

Perhaps the source of DS in this case is associated with the lipoxygenase pathway of arachidonic acid metabolism, resulting in the formation of leukotrienes. These inflammatory mediators, in addition to the pro-inflammatory properties, have a systemic vasoconstrictor effect, and are also powerful stimulants of the contractile ability of the smooth muscles of the respiratory tract and myometrium. Distreptaza, as a local anti-inflammatory medication, improves blood circulation and microcirculation in the small pelvis, helps to reduce and quickly eliminates puffiness and tissue infiltration, and has a quick analgesic effect, since it is used as rectal suppositories and has a minimal systemic effect on the whole body.

Distreptaza was prescribed during the use of Dysmenorm for 2-3 days before menstruation and on the first day of painful menstruation (for relief of a pain attack), 1-2 suppositories 1-2 times a day.

Group III patients received conventional therapy with analgesics and antispasmodics in usual dosages.

The developed non-hormonal therapy regimens were used in the complex of staged rehabilitation of teenage girls. The criteria for clinical effectiveness were: reduction or disappearance of pain, manifestations of vasovegetative disorders, normalization of menstrual function, improvement of the general somatic state of health and quality of life of patients.

The treatment efficiency in group I was $83.3 \%$ (the use of MRT without Dysmenorm was $75 \%$ [10], the treatment efficiency in group II was also high, - 76.6\%, in group III the treatment efficiency was significantly lower than in the first two groups and amounted to only $53.6 \%$. The decrease or complete disappearance of pain in patients of the first two groups was accompanied by an improvement in the general condition of patients, normalization of hemodynamics, disappearance or a significant reduction in vasovegetative disorders. Positive effect of treatment and timing of onset (relative to the relief of pain attack) were more common in patients with mild to moderately severe forms of DS. Most of these girls 
continued to have painless menstruation for 2-3 cycles secondary to the developed treatment.

\section{Conclusions}

Thus, the use of the developed schemes of combined complex treatment using Dysmenorm and Distreptaza is an effective non-hormonal method for treating dysmenorrhea syndrome in adolescence without adverse reactions and complications. The use of Dysmenorm in the treatment complex with the physiotherapeutic MRT method increases its effectiveness and helps to reduce the recurrence of pain in the process of stage rehabilitation.

In girls with extragenital disorders, in parallel with a positive gynecological effect with respect to menstrual function, the general condition of the body improved and vasovegetative manifestations disappeared. Administration of these schemes for 3 menstrual cycles during the stage of rehabilitation gave a positive clinical effect from 76.6 to $83.3 \%$, was not accompanied by adverse reactions and complications, and helped to increase the duration of the therapeutic clinical effect.

\section{Literature}

1. Богданова Е. А Гинекология детей и подростков. - М.: Мед» информ. агентство, $2000,-330$ с.

2. Богданова Е.А., Адамян Л.В., Сибирская Е.В., Глыбина Т.М. Гинекологическая патология у детей и подростков как причина абдоминального синдрома. // Проблемы репродукции. - 2011; 1: С. 28-35.

3. Вовк І. Б. Сексуальна просвіта підлітків: крок до збереження репродуктивного здоров’я / І.Б. Вовк, Л, М.Новік, М, М.Дідик // Буковин.мед.вісник. - 2004. -Т. 8., №2.C. 9-13.

4. Гуркин Ю.А. Гинекология подростков: Руководство для врачей. - СПб.: Фолиант, 2000. - 574 с.

5. Тучкина I.О. Етапна реабілітація підлітків 3 гінекологічними захворюваннями та юних вагітних 3 екстрагенітальною патологією / Автореф. дис...... д.мед.наук 14.01.01 Акушерство та гинекология. - 2007, Харків, ХНМУ.

6. Руководство по эндокринной гинекологии / под.. ред. Е.М.Вихляевой. - М. : ООО «Медицинское информационное агентство», 2006. - 7845 с.

7.Богданова Е.А. Практическая гинекология молодых. М.: Медицинская книга; 2011: 268.

8. Стандартные принципы обследования и лечения детей и подростков с гинекологическими заболеваниями и нарушениями полового развития // Под ред.. 
В.И.Кулакова, Е.В.Уваровой, Х.: Триада, 2004. - 136 с.

9. Тучкина И. А. Диагностика и гормональная коррекция нарушений менструальной функции у подростков в процессе поэтапной реабилитации // Репродуктивное здоровье женщины. - 2002. - №2. (11) - С.77-79.

10. Паращук Ю.С., Тучкина И. А. Негормональное лечение девочек-подростков c патологией пубертатного периода в комплексной этапной реабилитации реабилитации // Експериментальна і клінічна медицина. - 2005. - № 2. -С. 144-147.

11. Тучкина И. А. Клиническая эффективность резонансной терапии у девочекподростков с синдромом альгодисменореи на фоне экстрагенитальной патологии // Вестник физиотерапии и курортологии. - 2003. - № 3. - С. 55-57.

\section{REFERENCES}

1. Bohdanova E. A. Hinekolohiya ditey i pidlitkiv / YE. A. Bohdanova. - M .: Med inform. ahent.stvo, 2000., $-330 \mathrm{~s}$.

2. Bohdanova E.A., Adamyan L.V., Sybirs'ka YE.V., Hlybina T.M. Hinekolohichna patolohiya $\mathrm{u}$ ditey i pidlitkiv yak prychyna abdominal'noho syndromu. // Problemy reproduktsiyi. - 2011 roku; 1: S. 28-35.

3. Vovk I. B. Seksual'na prosvita pidlitkiv: krok do Zberezhennya reproduktyvnoho zdorov'ya / I.B. Vovk, L, M.Novik, M, M.Didik // Bukovin.med.visnik. - 2004. -T. 8., №2.-S. 9-13.

4. Hurkin YU.A. Hinekolohiya pidlitkiv: Kerivnytstvo dlya likariv. - SPb .: Foliant, 2000. $-574 \mathrm{~s}$.

5. Tuchkina I.O. Etapna reabilitatsiya pidlitkiv $\mathrm{z}$ hinekolohichnimi zakhvoryuvannyami ta yunykh vahitnykh z ekstrahenital'noyu patolohiyeyu / Avtoref. dys. ... .. D.med.nauk 14.01.01 Akusherstvo ta hinekolohiya. - 2007, Kharkiv, KHNMU.

6. Kerivnytstvo po endokrynnoyi hinekolohiyi / pid .. red. E.M.Vikhlyaevoy. - M.: TOV «Medychne informatsiyne ahent·stvo», 2006. - $7845 \mathrm{~s}$.

7. Bohdanova E.A. Praktychna hinekolohiya molodykh. M .: Medychna knyha; 2011: 268.

8. Standartni pryntsypy obstezhennya i likuvannya ditey i pidlitkiv $\mathrm{z}$ hinekolohichnymy zakhvoryuvannyamy i porushennyamy statevoho rozvytku // Pid red .. V.I.Kulakova, E.V.Uvarovoy, KH .: Triada, 2004. - 136 s.

9. Tuchkina I. A. Diahnostyka i hormonal'na korektsiya porushen' menstrual'noyi funktsiyi u pidlitkiv v protsesi poetapnoyi reabilitatsiyi // Reproduktyvne zdorov'ya zhinky. - 
2002. - №2. (11) - S.77-79.

10. Parashchuk YU.S., Tuchkina I. A. Nehormonal'nyy likuvannya divchatok-pidlitkiv $\mathrm{z}$ patolohiyeyu pubertatnoho periodu $\mathrm{v}$ kompleksniy etapnoyi reabilitatsiyi reabilitatsiyi // Eksperymental'na y klinichna medytsyna. - 2005. - № 2. -S. 144-147.

11. Tuchkina I. A. Klinichna efektyvnist' rezonansnoyi terapiyi u divchatok-pidlitkiv z syndromom al'hodysmenorey na tli ekstrahenital'noyi patolohiyi // Visnyk fizioterapiyi ta kurortolohiyi. - 2003. - № 3. - S. 55-57. 